\title{
Clematis coahuilensis (Ranunculaceae), a new species from north-central Mexico ${ }^{1}$
}

\author{
David J. Keil \\ Department of Botany and Microbiology \\ Arizona State University, Tempe, Arizona 85281 \\ KeIL, D. J. (Dept. Bot. Microbiol., Arizona State Univ., Tempe 85281). Clematis \\ coahuilensis (Ranunculaceae), a new species from north-central Mexico. Bull. Torrey \\ tainous regions of Coahuila, Durango, and Nuevo León, Mexico. The new species is a
} Bot. Club 104: 10-11. 1977.-Clematis coahuilensis is described as new from mounmember of sect. Clematis and is contrasted with $C$. dioica L. and C. drummondii T. \& G.

Floristic investigations in the Cuatro Ciénegas basin and nearby mountain ranges in Coahuila, Mexico, have resulted in the discovery of a previously undescribed species of Clematis (Ranunculaceae). The new species, Clematis coahuilensis, is apparently restricted to the Chihuahuan Desert Region and adjacent segments of the Sierra Madre Oriental. Its known distribution is centered in Coahuila.

Clematis coahuilensis is a member of sect. Clematis. The closest relatives appear to be two rather dissimilar species, $C$. dioica L., a widespread tropical American taxon. and $C$.drummondii T. \& G., a common plant of arid regions of North America. Clematis coahuilensis is allopatric with $C$. dioica but is geographically sympatric with $C$. drummondii.

The principal similarities between $C$. coahuilensis and $C$. dioica are vegetative. Leaves of both species are once pinnate with $3-5(-7)$ ovate, entire to few-dentate or shallowly lobed, often coriaceous leaflets. Leaves of $C$. coahuilensis are generally smaller than those of $C$. dioica, although leaf size is rather variable in both taxa. Inflorescences of $C$. dioica are usually axillary or terminal, long-peduncled corymbiform compound cymes. In C. coahuilensis flowers are solitary or clustered in few-

1 I would like to thank Dr. Donald J. Pinkava for bringing this new species to my attention and for his support and encouragement throughout the study. I am grateful to Dr. Marshall C. Johnston and Dr. James S. Pringle for reviewing the manuscript.

2 Present address: Biological Sciences Dept., California Polytechnic State University, San Luis Obispo, CA 93407.

Received for publication June 8, 1976. flowered sessile or short-peduncled cymes. In some individuals of $C$. coahuilensis, cymes are loosely aggregated into paniculiform clusters (Fig. 1).

Clematis drummondii is vegetatively quite distinct from $C$. coahuilensis but has similar inflorescence form. Leaves of $C$. drummondii are very long-petiolate and are once or sometimes twice-pinnate. Leaflets are usually deeply incised with the terminal lobe elongate and often falcate. Margins of the lobes are either slightly convex-curved or weakly concave-curved. Pedicels in $C$. drummondii range from 0.5 to $0.9 \mathrm{~mm}$ diameter whereas those of $C$. coahuilensis are more slender $(0.3-0.5 \mathrm{~mm}$ diameter). Styles of $C$. coahuilensis seldom exceed $3.5 \mathrm{~cm}$ in length, but in $C$. drummondii, styles are very elongate, ranging from 4 to $10 \mathrm{~cm}$.

Although $C$. coahuilensis and $C$. drummondii occur in the same regions, they are ecologically distinct. Clematis coahuilensis grows in upland canyons between 1200 and $2400 \mathrm{~m}$ in the oak-pine woodland and chaparral scrub zones. Clematis drummondii is widespread mostly at lower elevations. It is particularly common along roadsides and fences where the long plumose styles of its fruits make it a conspicuous element of the flora.

Clematis coahuilensis Keil, sp. nov.

Frutex scandens caulibus usque ad 3 vel $4 \mathrm{~m}$ longis, infra inflorescentes internodis $4-13 \mathrm{~cm}$ longis et $1-2 \mathrm{~mm}$ diametro, virescentibus vel atrospadiceis sexangularibus tomentosis vel glabrescentibus. Folia semel pinnata, plerumque $6-11 \mathrm{~cm}$ longa; petioli exiles interdum volubiles, $1.0-4.5 \mathrm{~cm}$ longi, villoso-tomentosi; rhaches 1-4 cm longi, villoso-tomentosi ; foliola 3-7, 

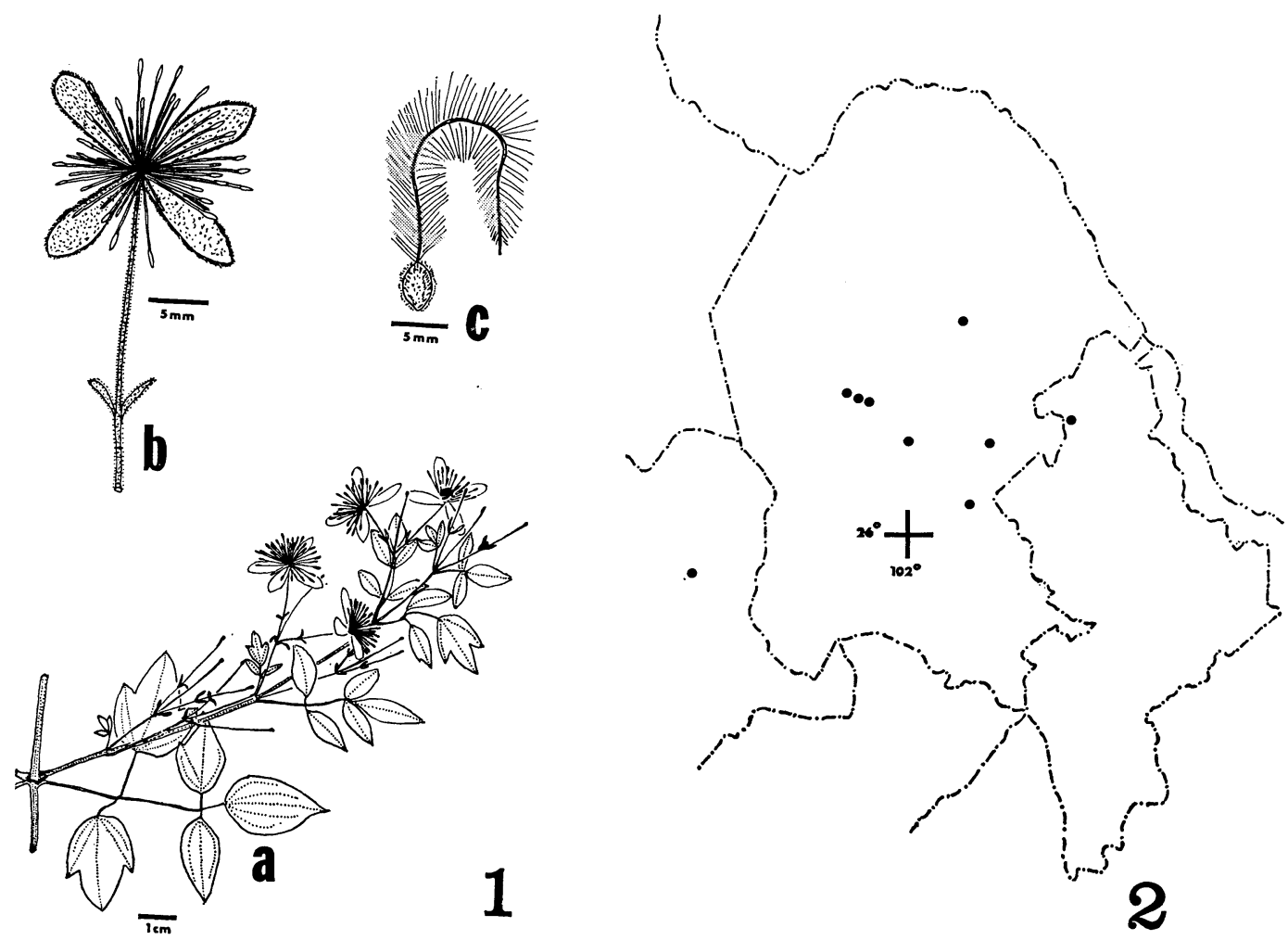

Figs. 1-2. Clematis coahuilensis, sp. nov.-Fig. 1. a, habit; b, staminate flower; c, mature achene. -Fig. 2. Geographic distribution of Clematis coahuilensis.

sessilia usque longipetiolulata, subcoriacea, late lanceolata usque ovata, 1-5-nervata, 2-5 (-6) cm longa et 1-3 (-5) cm lata, integra usque paucidentata et/vel trilobata dentibus apice mucronatis, marginibus foliolorum loborumque convexis, basibus rotundatis vel subcordatis, apicibus obtusis usque acuminatis, utrinque atrivirentia seu subtus parum pallentioria, utrinque pilosa trichomatibus exilibus $0.3-0.8 \mathrm{~mm}$ longis aut glabrescentia, subtus stomatophora. Cymae 1-5-florae floribus nune solitariae axillaresque nunc in paniculis foliosis usque ad $20 \mathrm{~cm}$ longis, pedicellis filiformibus $0.3-$ $0.5 \mathrm{~mm}$ diametro, $0.7-2.5 \mathrm{~cm}$ longis, tomentosis. Flores staminati $2 \mathrm{~cm}$ diametro, receptacula conica hirtella, sepalis 4 , eburneis oblanceolatis circa $1 \mathrm{~cm}$ longis $3-4 \mathrm{~mm}$ latis patentibus utrinque tomentulosis, staminibus numerosis usque ad circa $8 \mathrm{~mm}$ longis, interdum aliquot pistillis rudimentalibus. Flores pistillati non visi. Receptaculum fructiferum conicum hirtellum. Achenia complanata elliptica, $3.5-4.0 \mathrm{~mm}$ longa, 2.0-2.5 $\mathrm{mm}$ lata, atroporphyrea, hirtella, stylibus plumosis $2-4 \mathrm{~cm}$ longis. Chromosomatum numerus ignotus.
Type: Mexico: Coahuila: Sierra de la Madera, Cañón de la Hacienda, $1400 \mathrm{~m}$, 4 Aug 1973, ơ, J. Henrickson \& T. Wendt 11880 (holotype, LL; isotypes, ASU, remainder to be distributed).

Clematis coahuilensis is known from mountainous areas of Coahuila, northeastern Durango, and western Nuevo León (Fig. 2) and is known in flower or fruit from late June to mid-September.

Additional specimens examined: Mexico: Coahuila: Sierra de la Madera, Cañón de la Charretera, 9, I. M. Johnston 9131 (GH, LL), ô, 9131A (GH, LL) ; Cañón de la Gavia, S of Rancho de la Gavia, ${ }^{\lambda}, M$. C. Johnston et al. 12046 (LL) ; Muzquiz, Mariposa Ranch, Palm Canyon, + , Marsh $7 d$ (TEX) ; Sierra de la Gloria, ${ }^{\lambda}$, Marsh 1865 (GH), ô, Marsh 1981 (GH, TEX); Sierra de la Madera, Cañón del Pajarito, ô, + , Muller 3155 (GH, LL); Sierra de San Marcos, $4 \mathrm{mi}$ NW of Poso de los Fresnos, bud only, Reeves \& Pinkava P13163 (ASU). Durango: NW third of Sierra del Rosario, ơ, M. C. Johnston et al. $11459 C$ (LL). Nuevo León: Lampazos, ${ }^{\lambda}$, Taylor 353 (TEX). 